\title{
IMPLIKASI YURIDIS PENETAPAN DIREKSI BPR BERBENTUK PT BERDASARKAN POJK NOMOR 20/POJK.03/2014 TENTANG BPR
}

\author{
Evina Dhana Hermansyah
}

\author{
PT. Taman Dayu \\ Jl. Raya Surabaya Malang KM. 48 Kec. Pandaan Pasuruan \\ Email: evina.dhana@gmail.com
}

\begin{abstract}
Financial Services Authority (Otoritas Jasa Keuangan / OJK) has issued Regulation Number 20/POJK.03/2014 Regarding Bank Perkreditan Rakyat ("Regulation"). According to the Regulation, in case one of the members of Board of Director is vacant, BPR shall immediately purpose candidate of Director of company to OJK. Pursuant to the Regulation, BPR should obtain the candidate of its Director within 120 (one hundred and twenty) days after the position is vacant. The candidate(s) of Director should meet the requirements stated in the Regulation with a fit and proper test held by OJK, otherwise, it will not be approved. The objectives of this research are (i) to analyze the impact of POJK regarding the procedure for appointment of Directors (ii) also, to analyze how BPR should undertake legally before OJK states Board of Directors for a BPR. In several cases, if the candidate does not meet the requirements, $B P R$ may propose candidate of Director to OJK more than 2 (two) times which may not comply with the Regulation regarding minimum number of Board of Director. According to Regulation, this shall be subject to sanction. The research is compiled by normative juridical methods through statute approach. As the result of research, submission of candidate of Board of Director stated in Regulation does not reflect certainty of law, especially to BPR. The Regulation may not comply with the minimum number of Board of Director for a long period although it is not purely the responsibility of BPR. With an uncompleted number of Board of Director, BPR could not act properly as a legal entity.
\end{abstract}

Key words: OJK regulation, $B P R$, board of director of $B P R$

\begin{abstract}
Abstrak
Sejak Otoritas Jasa Keuangan ("OJK") mengeluarkan Peraturan Otoritas Jasa Keuangan Nomor 20/POJK.03/2014 tentang Bank Perkreditan Rakyat ("POJK”), maka dalam Bank Perkreditan Rakyat ("BPR") wajib mengikuti ketentuan di dalamnya termasuk dalam hal penetapan anggota Direksi dan Dewan Komisaris. Dalam hal salah satu anggota Direksi BPR tidak terisi, maka BPR menetapkan pengganti anggota Direksi penggantinya kepada OJK berdasarkan POJK. POJK menetapkan jangka waktu 120 (seratus dua puluh) hari kepada BPR untuk menetapkan Direksi pengganti. Nama calon anggota Direksi yang diajukan BPR kepada OJK tidak serta merta diterima oleh OJK. Calon anggota Direksi yang diajukan tersebut harus memenuhi kriteria dan persyaratan yang ditetapkan oleh OJK. Jurnal ini ditulis untuk menganalisis implikasi yang timbul terhadap BPR sehubungan dengan penetapan anggota Direksi berdasarkan POJK. Selain itu, penulisan jurnal ini juga untuk mengetahui bagaimana bentuk perbuatan hukum yang dilakukan selama susunan anggota Direksinya belum memenuhi ketentuan POJK. Dalam beberapa kasus, BPR dapat berkali-kali mengajukan permohonan calon anggota Direksinya sehingga BPR melewati batas waktu yang ditentukan dalam POJK untuk memenuhi jumlah
\end{abstract}


minimum anggota Direksi. Secara normatif berdasarkan POJK, BPR dapat dikenai sanksi atas tidak terpenuhinya jumlah minimum anggota Direksi walaupun hal tersebut bukanlah mutlak kesalahan BPR. Jurnal ini disusun dengan metode penelitian yuridis normatif dengan pendekatan peraturan perundang-undangan. Berdasarkan hasil penelitian, ketentuan dalam POJK ini sehubungan dengan penetapan anggota Direksi BPR masih belum memberikan kepastian hukum bagi BPR. Ketentuan di dalam POJK terkait dengan pelaksanaan peneteapan anggota Direksi BPR dapat menyebabkan BPR tidak memenuhi jumlah minimum anggota Direksi untuk jangka waktu yang relatif lama. BPR yang tidak memenuhi jumlah minimal anggota Direksi menyebabkan BPR tersebut tidak memiliki organ yang utuh sebagai suatu badan hukum.

Kata kunci: peraturan OJK, BPR, penetapan direksi

\section{Latar Belakang}

Otoritas Jasa Keuangan ("OJK") ${ }^{1}$ telah menetapkan sejumlah kebijakan baru yang salah satu diantaranya adalah mengenai aspek pendirian dan operasional BPR. Kebijakan mengenai aspek pendirian dan operasional BPR. Kebijakan tersebut ditetapkan dalam Peraturan Jasa Keuangan Nomor 20/ POJK.03/2014 tentang Bank Perkreditan Rakyat. Aturan yang mulai berlaku efektif per 1 Januari 2015 ini garis besarnya menetapkan beberapa aspek diantaranya mengenai: (a) penetapan jumlah modal disetor dalam rangka pendirian BPR yang ditetapkan ke dalam 4 (empat) zona operasi BPR, (b) mekanisme perizinan BPR dimana proses perizinannya akan dilakukan secara terpusat, (c) susunan kepemilikan saham pengendali BPR, yakni BPR wajib memiliki minimal 1 (satu) pemegang saham dengan prosentase kepemilikan saham tidak kurang dari 25\% (dua puluh lima persen), (d) kualifikasi pengurus BPR, termasuk di dalamnya mengenai pembatasan hubungan keluarga dalam satu susunan kepengurusan BPR dan larangan merangkap jabatan bagi pengurus BPR, (e) prosedur pembukaan jaringan kantor oleh BPR sesuai dengan tingkat kesehatannya, (f) mekanisme pencabutan izin usaha atas permintaan pemegang sahan BPR (self liquidation).

Ditinjau dari substansinya, apa yang telah diatur dalam Peraturan Otoritas Jasa Keuangan Nomor 20/POJK.03/2014 tentang Bank Perkreditan Rakyat ini bertujuan untuk memperkuat daya saing BPR di era globalisasi ini dan untuk melindungi kepentingan konsumen dan masyarakat. Menurut Ketua Umum Perhimpunan Bank Rakyat Indonesia (Perbarindo), Regulasi baru OJK (Peraturan Otoritas Jasa Keuangan Nomor 20/POJK.03/2014) akan memperkuat daya saing BPR di tengah persaingan yang makin ketat pada Masyarakat Ekonomi Asean (MEA). ${ }^{2}$ Mengingat tujuan dibentuknya OJK adalah agar kegiatan di sektor jasa keuangan

1 Otoritas Jasa Keuangan, dalam jurnal ini disingkat OJK.

2 Suara Merdeka, "Peraturan OJK Memperkuat BPR", http://berita.suaramerdeka.com/smcetak/peraturan-baruojk-memperkuat-bpr/, diakses 6 Juni 2015. 
dapat terselenggara secara teratur, adil, transparan dan akuntabel, maka hal yang tidak kalah pentingnya adalah bagaimana OJK mengimplementasikan apa yang telah diaturnya.

Penelitian ini akan mengkhususkan pada berlakunya Peraturan Otoritas Jasa Keuangan Nomor 20/POJK.03/2014 terhadap BPR yang berstatus Perseroan Terbatas. BPR yang berbentuk perseroan terbatas tidak hanya tunduk pada undang-undang yang berkaitan dengan badan hukum perseroan terbatas tapi juga berkaitan dengan perundang-undangan yang mengatur mengenai hukum perbankan.

Salah satu organ perseroan yang paling bertanggung hawab dalam pengelolaan dan kepengurusan perseroan adalah direksi. Menyinggung kepengurusan bank, ada 3 (tiga) unsur penting di dalam Undangundang Nomor 7 Tahun 1992 jo Undangundang Nomor 10 Tahun 1998, yaitu (i) susunan organisasi dan kepengurusan bank; (ii) kepemilikan; (iii) keahlian di bidang perbankan. Begitu pentingnya ketiga unsur tersebut, OJK pun memasukkannya ke dalam Peraturan OJK Nomor 20/POJK.03/2014 tentang BPR.

Susunan pengurus inti BPR terdiri dari Direksi dan Dewan Komisaris. Baik Direksi maupun Dewan Komisaris BPR sekurang-kurangnya terdiri dari 2 (dua) orang yang harus memeuhi persyaratan (i) kompetensi, (ii) integritas, dan (iii) reputasi keuangan menempuh fit and proper test yang diselenggarakan oleh OJK dan memiliki sertifikat kelulusan yang dikeluarkan oleh Lembaga Sertifikasi Profesi. ${ }^{3}$ Syarat dan ketentuan anggota Direksi dan Komisaris yang diatur dalam Peraturan OJK Nomor 20/ POJK.03/2014 bertujuan untuk menetapkan anggota Direksi maupun Dewan Komisaris yang memiliki kompetensi dan integritas sebagai pengurus bank. Sehat atau tidaknya suatu BPR, juga bergantung pada para pengurusnya sehingga dapat dipahami mengapa Bank Indonesia dan OJK membuat aturan dan kebijakan yang ketatnya persyaratan untuk menjadi anggota Direksi. Direksi sebagai salah satu pilar utama dalam mengurus perseroan dapat diibaratkan sebagai nahkoda perseroan, pusat energi perseroan, mesin perseroan, semangat perseroan, corporate image yang utama dari perseroan dan simbol perseroan. ${ }^{4}$

Peraturan OJK Nomor 20/POJK.03/2014 tentang BPR mensyaratkan bahwa anggota Direksi BPR paling sedikit berjumlah 2 (dua) orang dimana salah satunya menjabat sebagai Direktur Utama. ${ }^{5}$ Bahkan, sebelum berlakunya Peraturan OJK Nomor 20/POJK.03/2014 tentang BPR, Undang-undang Perseroan Terbatas pun mensyaratkan bahwa untuk direksi perseroan terbatas yang berusaha di bidang perbankan wajib mempunyai

3 Peraturan OJK Nomor 20/POJK.03/2014.

4 Try Widiyono, Direksi Perseroan Terbatas, (Bogor: Ghalia Indonesia, 2008), hlm. 41.

5 Pasal 1, Peraturan OJK Nomor 20/POJK.03/2014. 
direksi paling sedikit 2 (dua) orang. ${ }^{6}$ Dengan demikian, pengangkatan anggota Direksi bank umum dan BPR wajib memenuhi persyaratan yang ditetapkan oleh OJK, termasuk namun tidak terbatas pada fit and proper test yang diselenggarakan oleh OJK.

Pada prakteknya, ada kalanya suatu BPR tidak dapat memenuhi jumlah minimum yang ditetapkan oleh undang-undang dan OJK. Permasalahan tersebut bisa disebabkan (i) salah satu anggota direksi meninggal dunia atau mengundurkan diri dari jabatannya sebelum masa jabatannya berakhir (ii) salah satu anggota direksi diberhentikan oleh RUPS. Dengan demikian, berdasarkan Peraturan OJK Nomor 20/POJK.03/2014, seharusnya BPR segera mengajukan permohonan untuk persetujuan calon anggota direksinya. OJK di dalam peraturan yang dibuatnya menetapkan tata cara mulai dari pelaporan perihal meninggal atau mengundurkannya anggota Direksi hingga tata cara pengajuan permohonan pengajuan calon anggota Direksinya. Sebagaimana telah disinggung sebelumnya, berdasarkan Peraturan OJK Nomor 20/ POJK.03/2014, setiap pengangkatan anggota Direksinya, BPR harus mendapat persetujuan dari OJK dan calon anggota Direksi yang diajukan ke OJK harus melalui fit and proper test yang diselenggarakan oleh OJK. Di sisi lain, berdasarkan Peraturan OJK Nomor 20/ POJK.03/2014, dalam hal posisi anggota Direksi lowong, BPR harus segera melakukan penggantian anggota Direksi dalam jangka waktu tertentu. Ketentuan-ketentuan pada Peraturan OJK Nomor 20/POJK.03/2014 inilah yang akan diteliti penulis dalam penelitian ini dengan rumusan masalah (i) Apakah implikasi yuridisnya terhadap BPR atas pelaksanaa Peraturan OJK Nomor 20/ POJK.03/2014 sehubungan dengan penetapan Direksi BPR yang berbadan hukum Perseroan Terbatas?; (ii) Bagaimanakah bentuk perbuatan hukum yang dilakukan oleh Rapat Umum Pemegang Saham ("RUPS") untuk mengisi kekosongan anggota Direksinya selama menunggu penetapan Direksi oleh OJK berdasarkan Peraturan OJK Nomor 20/ POJK.03/2014.

Jurnal ini disusun berdasarkan metode penelitian hukum normatif, yang dilakukan dengan pendekatan perundang-undangan (statuta approach), yang didukung dengan bahan hukum primer berupa peraturan perundang-undangan yang terkait dan buku-buku hukum yang relevan dengan permasalahan yang diangkat dalam jurnal ini.

\section{Pembahasan}

\section{A. Penetapan Direksi Berdasarkan POJK}

\section{Persyaratan keanggotaan direksi}

Bank sebagai badan hukum yang berbentuk perseroan terbatas, maka pada BPR berlaku asas-asas umum dalam perseroan terbatas. Eksistensi dan fungsi direksi bank pada dasarnya sama dengan eksistensi dan fungsi

6 Pasal 92 ayat 4, Undang-undang Nomor 40 Tahun 2007. 
direksi perseroan terbatas. Namun, terdapat ketentuan-ketentuan lain yang melengkapi ketentuan-ketentuan yang hanya berlaku pada direksi perseroan terbatas. Adanya pengaturan yang lebih spesifik mengenai direksi bank, dalam hal ini BPR, memberikan gambaran bahwa dunia perbankan mempunyai karakteristik yang berbeda dengan bidang usaha lainnya.

Undang-undang Nomor 40 Tahun 2007 tentang Perseroan Terbatas (“UUPT") 7 secara umum menetapkan bahwa suatu perseroan sekurang-kurangnya diurus oleh 1 (satu) orang direksi satu lebih dari 1 (satu) orang direksi, dengan pengecualian bagi perseroan yang bidang usahanya melakukan pengerahan dana masyarakat harus memiliki sekurangkurangnya 2 (dua) orang anggota direksi. Demikian halnya dengan UU Perbankan dan Peraturan OJK yang menetapkan bahwa anggota Direksi BPR paling sedikit berjumlah 2 (dua) orang ${ }^{8}$, yang salah satu diantaranya bertindak selaku Direktur Utama.

UUPT tidak membatasi keanggotaaan Direksi dalam perseron, baik Warga Negara Indonesia maupun Warga Negara Asing dapat menjadi anggota Direksi perseroan, namun dalam UUPT disyaratkan bahwa anggota Direksi haruslah orang perorangan. Kalimat orang perseorangan dalam Pasal 93 UUP menunjukkan "manusia" (natura person) dan melarang anggota Direksi dijabat oleh suatu "badan usaha" (corporate directors) sebagaimana pada praktek di beberapa negara lain. ${ }^{9}$ Kepengurusan perseroan tidak dapat dilakukan oleh badan hukum perseroan maupun oleh badan usaha baik yang berbadan hukum maupun yang tidak berbadan hukum. ${ }^{10}$ Lebih lanjut Pasal 93 ayat (1) UUPT menetapkan syarat umum menjadi anggota Direksi, diantaranya cakap melakukan perbuatan hukum namun ada saringan yang harus dilewati yakni selama jangka waktu 5 (lima) tahun sebelum pengangkatannya calon tersebut harus (i) tidak pernah dinyatakan pailit, (ii) menyebabkan suatu perseroan dinyatakan pailit selama masa pengurusannya sebagai anggota Direksi atau Dewan Komisaris, (iii) tidak pernah dihukum karena suatu tindak pidana yang merugian keuangan negara.

Selanjutnya dalam Pasal 93 ayat (2) UUPT memberikan kewenangan kepada instansi teknis yang berwenang untuk menetapkan persyaratan tambahan untuk pengangkatan anggota Direksi berdasarkan peraturan perundang-undangan. Sebagaimana dijelaskan sebelumnya pada bab sebelumnya, sejak berlakunya Undang-undang Nomor 21 Tahun 2011 tentang OJK ("UUOJK"), maka pengawasan dan pengaturan terhadap lembaga jasa keuangan, termasuk di dalamnya BPR,

7 Undang-undang Nomor 40 Tahun 2007 tentang Perseroan Terbatas.

8 Pasal 92 ayat (4) UUPT.

9 Cornelius Simanjuntak dan Natalie Mulia, Organ Perseroan Terbatas, (Jakarta: Sinar Grafika, 2009), hlm. 28.

10 Ahmad Yani dan Gunawan Widjaja, Seri Hukum Bisnis Perseroan Terbatas, (Jakarta: Rajawali Pers, 1999), hlm. 99. 
dipegang oleh OJK. Melalui Peraturan OJK, OJK menetapkan bahwa persyaratan untuk menjadi anggota Direksi BPR, seseorang haruslah memenuhi persyaratan kompetensi, integritas dan reputasi keuangan ${ }^{11}$ dan untuk memenuhi ketiga persyaratan tersebut, seorang calon anggota Direksi BPR harus mengikuti uji kemampuan dan kepatutan. ${ }^{12}$ Kompetensi dan integritas yang baik dinilai dari ${ }^{13}$ :

a. akhlak dan moral yang baik.

b. mamatuhi peraturan perundangundangan yang berlaku.

c. memiliki komitmen yang tinggi terhadap pengembangan operasional bank yang sehat.

d. memiliki kemampuan dalam menjalankan tugas.

Selain persyaratan yang telah disebutkan tersebut, anggota Direksi haruslah ${ }^{14}$ :

a. Bertempat tinggal di kota/kabupaten yang sama; atau di kota/kabupaten yang berbeda namun masih dalam propinsi yang sama; atau di kota/kabupaten yang berbeda propinsi namun berbatasan dengan tempat kedudukan BPR.

b. Berpendidikan formal minimal setingkat diploma tiga

c. Memiliki pengetahuan yang memadai di bidang perbankan dan memiliki pengalaman di bidang perbankan setidaknya selama 2 (dua) tahun serta memiliki kemampuan pengelolaan strategis.

Persyaratan untuk menjadi seorang anggota Direksi BPR tidaklah mudah. Dengan seluruh ketentuan yang disebutkan di atas, pastilah seorang calon anggota Direksi BPR memiliki kemampuan dan keahlian di bidang keuangan, khususnya di bidang perbankan. Pernyataan ini didasari pada persyaratan pada Pasal 26 Peraturan OJK bahwa seorang Direksi harus memiliki pengetahuan yang memadai di bidang perbankan. Yang dimaksud dengan pengetahuan adalah pengetahuan mengenai peraturan-peraturan yang terkait dengan BPR dan mengetahui seluk beluk operasional BPR. Selain pengetahuan, seorang calon anggota Direksi BPR harus memiliki pengalaman dan keahlian di bidang perbankan, yang mana pengalaman dan keahlian dimaksud antara lain dalam bidang operasional, pemasaran, pembukuan dan hal-hal lainnya terkait dengan kegiatan BPR. Kompetensi yang ditetapkan oleh OJK untuk calon anggota Direksi ini harus dibuktikan pula berdasarkan sertifikat kelulusan yang dikeluarkan oleh Lembaga Sertifikasi Profesi. ${ }^{15}$

Selain ketentuan-ketentuan yang telah disebutkan di atas, Pasal 27 POJK menetapkan adanya pembatasan hubungan keluarga di dalam suatu BPR, larangan kepemilikan saham mayoritas di perusahana lain dan larangan rangkap jabatan oleh Direksi. Untuk lebih jelasnya, berikut ketentuan yang diatur dalam Pasal 27 POJK:
11 Pasal 24 ayat (1) POJK.

12 Pasal 24 ayat (2).

13 Peraturan Bank Indonesia No. 2/27/PBI/2000.

14 Pasal 25 POJK.

15 Pasal 26 POJK. 
1. Mayoritas anggota Direksi dilarang memiliki hubungan keluarga atau semenda sampai dengan derajat kedua dengan sesama anggota Direksi dan/atau anggota Dewan Komisaris.

2. Anggota Direksi baik secara sendirisendiri maupun bersama-sama dilarang memiliki saham sebesar $25 \%$ atau lebih dari modal disetor pada bank dan/atau menjadi pemegang saham mayoritas di lembaga jasa keuangan non bank.

3. Anggota Direksi dilarang merangkap jabatan pada bank, perusahaan non bank dan/atau lembaga lain kecuali sebagai pengurus asosiasi industri BPR dan/ atau lembaga pendidikan dalam rangka peningkatan kompetensi BPR sepanjang tidak mengganggu pelaksanaan tugas sebagai Direksi BPR, dan seterusnya.

Ketentuan ini tentunya untuk meminimalisir adanya conflict of interest dalam pengambilan keputusan operasional BPR.

Melalui Gambar 1, penulis menyajikan alur prosedur pengajuan calon direksi kepada OJK. (lihat Gambar 1)

Dalamhal prosedur permohonan penetapan direksi, ketentuan-ketentuan yang diatur dalam POJK isinya tidak bertentangan dengan UUPT maupun UU Perbankan. Baik di dalam UUPT dan UU Perbankan yang merupakan peraturan yang derajatnya lebih tinggi dibanding POJK, sama-sama menetapkan jumlah minimum anggota Direksi BPR sebanyak 2 (dua) orang. Kompetensi individu calon anggota Direksi yang ditetapkan dalam POJK pun tidak bertentangan dengan UUPT, antara lain:

a. calon anggota Direksi tidak pernah dinyatakan pailit atau menjadi anggota Direksi/Dewan Komisaris yang diputuskan menyebabkan suatu perseroan dinyatakan pailit ${ }^{16}$.

b. tidak pernah dihukum karena suatu tindak pidana.

Persyaratan administratif pengajuan calon anggota Direksi BPR dapat pula dilihat pada Surat Edaran Bank Indonesia Nomor 15/45/ DPNP tanggal 18 November 2013 tentang Perubahan Atas Surat Edaran Bank Indonesia Nomor 14/36/DKBU Tanggal 21 Desember 2012 Perihal Uji Kemampuan dan Kepatutan (fit and proper test) BPR. Di dalam Surat Edaran dimaksud, ada beberapa formulir yang harus dilengkapi oleh BPR dan calon Direksinya pada saat pengajuan fit and proper test.

Namun, menurut analisa penulis dalam Pasal 8 POJK, yang intinya menyatakan bahwa pada tahap pendirian BPR, persetujuan prinsip diajukan kepada Dewan Komisioner OJK oleh Pemegang Saham BPR (dalam hal ini Pemegang Saham Pengendali) dengan melengkapi dokumen persyaratan yang ditentukan dalam Pasal 8 POJK salah satunya adalah (i) rancangan akta pendirian dan (ii) daftar calon anggota Direksi dan anggota Dewan Komisaris. Hal ini berbeda dengan 
Gambar 1. Alur Prosedur Pengajuan Calon Direksi Kepada OJK

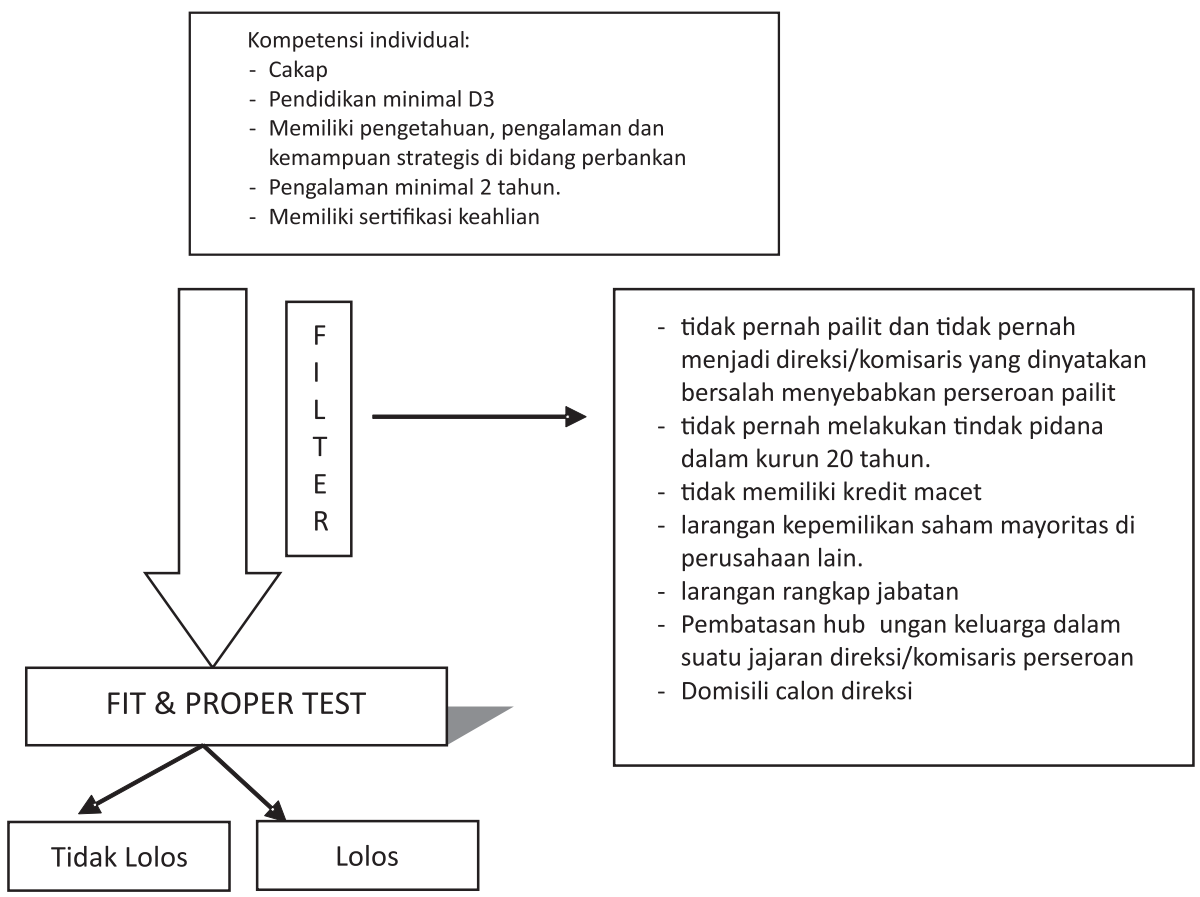

Sumber: Bahan hukum sekunder, diolah, 2015

ketentuan Pasal 94 UUPT yang menyebutkan bahwa untuk pertama kalinya pengangkatan Direksi dilakukan oleh pendiri perseroan dalam akta pendirian. Ini menandakan adanya tahapan "pra pendirian" bagi perseroan yang mempunyai usaha di bidang perkreditan rakyat. Bagi para pendiri BPR, mereka diwajibkan untuk memberikan daftar calon anggota Direksi dan anggota Dewan Komisarisnya yang nantinya calon anggota Direksi dan Dewan Komisaris tersebut akan melalui proses screening oleh OJK.

Setelah BPR mengajukan calon anggota Direksi, OJK akan memberikan persetujuan atau penolakan dimaksud selambat-lambatnya 30 (tiga puluh) hari sejak permohonan berikut dokumen yang dipersyaratkan lengkap diterima oleh OJK. ${ }^{17}$ Setelah OJK menyetujui calon Direksi yang diajukan oleh BPR, maka BPR harus segera menindaklanjutinya dengan mengadakan RUPS selambatlambatnya 90 (sembilan puluh) hari sejak tanggal persetujuan OJK untuk mengangkat Direksinya. ${ }^{18}$ Jika dalam 91 (sembilan puluh) hari BPR tidak mengadakan RUPS untuk menetapkan Direksinya, maka persetujuan dan penetapan hasil fit and prosper test atas calon Direksi dimaksud dinyatakan batal dan tidak berlaku. ${ }^{19}$

Di dalam Penjelasan UUOJK, ditegaskan mengenai status independensi OJK di dalam 
melaksanakan tugas dan kewenangannya, yaitu OJK bebas dari campur tangan pihak lain, kecuali untuk hal-hal lain yang diatur secara tegas di dalam UUOJK. Oleh karenanya, di dalam penentukan calon anggota Direksi yang diajukan oleh suatu BPR, OJK secara independen berhak untuk menentukan lolos dan tidaknya calon Direksi yang diajukan kepadanya. Pun pada prakteknya, untuk menetapkan calon anggota Direksi yang diajukan kepadanya, OJK memiliki independensi penuh yang tidak dapat diintervensi oleh pihak manapun. Pernah dalam suatu kasus, suatu BPR berkali-kali gagal mengajukan calon anggota Direksinya karena calon anggota Direksinya tidak lolos fit and proper test yang didadakan oleh OJK.

Begitu ketat dan rumitnya persyaratan yang ditetapkan oleh OJK tidak lain bertujuan untuk mewujudkan BPR dengan tata kelola yang baik. Dengan adanya persyaratan yang ditentukan berdasarkan POJK, diharapkan dapat tewujud good corporate governance di setiap BPR yang tumbuh di Indonesia. Direksi adalah tulang punggung suatu perusahaan. Baik buruknya perusahaan bergantung pada direksinya. Direksi dibebani tangung jawab pengelolaan perseroan berdasarkan UUPT dan anggaran dasar perseroan. Untuk itu, dengan penetapan yang sedemikian oleh OJK, diharapkan masing-masing BPR memiliki Direksi yang memiliki kompetensi, integritas yang sangat baik.

19 Pasal 30 ayat (6).
Bagi BPR, aturan yang ditetapkan dalam POJK dalam hal penetapan anggota Direksi ini membuat BPR harus benar-benar selektif dalam memilih calon Direksinya. BPR juga harus memiliki komitmen yang kuat terhadap praktek good corporate governance. Tanpa penerapan good corporate governance di dalam lingkungan perusahaan, perusahaan berpotensi menjadi tidak sehat. Nilai-nilai profesionalisme dapat diciptakan dengan menumbuhkan dan membudayakan budaya kerja yang jujur, adil, berintegritas, beretika, bermoral dan bertanggungjawab.

\section{Penetapan anggota direksi untuk menggantikan posisi anggota direksi yang lowong}

Dalam UUPT Pasal 94 ayat (1) dinyatakan bahwa anggota direksi diangkat oleh RUPS. Pasal 94 ayat (4) disebutkan bahwa anggaran dasar perseroan mengatur tata cara pengangkatan, penggantian, dan pemberhentian anggota Direksi juga menetapkan saat mulai berlakunya pengangkatan, penggantian dan pemberhentian tersebut.

Susunan anggota Direksi perseroan tidak terisi dapat disebabkan oleh:

a. kematian;

b. pengunduran diri;

c. pemberhentian oleh RUPS.

d. tidak memenuhi persyaratan yang ditetapkan oleh peraturan perundangundangan. 
Namun, bagi direksi BPR, di samping terdapat ketentuan pemberhentian yang ditetapkan dalam UUPT, terdapat "intervensi" dari OJK untuk melakukan pemberhentian jabatannya sebagai salah satu sanksi atas pelanggaran yang telah dilakukannya. Menurut Try Widiyono, seharusnya badan hukum lain tidak berhak untuk memberhentikan direksi perseroan lainnya sehingga semestinya tidak ada intervensi dari OJK untuk memberhentikan direksi suatu BPR. Menurut teori Organ yang dikemukakan oleh Van Girke, suatu perseroan sebagai suatu usaha mandiri dengan tanggung jawab terbatas, mempunyai kehendak dan kemauannya sendiri yang dijalankan oleh organnya, yang salah satunya adalah direksi perseroan. Seharusnya, direksi suatu BPR diberikan kepercayaan penuh untuk mengelola bank-nya. Namun kembali lagi kepada sifat usaha bank yang berbeda dengan jenis usaha lainnya, yang salah satu kegiatan usahanya mengumpulkan dana masyarakat. Adanya intervensi OJK sebagai suatu lembaga pengawas dapat diketahui adanya pelanggaran yang dilakukan oleh BPR, sehingga apabila terjadi suatu kesalahan yang membahayakan kepentingan masyarakat dan untuk mencegah tindakan penyimpangan yang dilakukan oleh direksi BPR, maka dengan ketentuan yang lebih khusus menyimpang dari ketentuan UUPT, OJK dapat memberhentikan direksi bank umum dan BPR. ${ }^{20}$
Setiap kejadian yang menyebabkan susunan Direksi BPR tidak terisi, maka dalam jangka waktu paling lama 10 (sepuluh) hari, BPR wajib menyampaikan laporan kepada OJK. ${ }^{21}$ Terhitung sejak tidak terisinya posisi Direksi, maka BPR pun harus segera mengadakan RUPS untuk menetapkan direksi baru. Pasal 33 POJK pun mengatur bahwa terhitung sejak setiap kejadian yang menyebabkan BPR tidak dapat memenuhi jumlah minimum anggota Direksinya berdasarkan sebab apapun sebagaimana yang diatur dalam Pasal 33 POJK, BPR wajib melakukan penggantian anggota Direksi paling lama 120 (seratus dua puluh) hari kerja.

Umumnya, untuk meminimalisir biaya operasional BPR, suatu BPR hanya mempunyai 2 (dua) orang anggota Direksi sehingga jika salah satu anggota Direksinya mengundurkan diri, BPR itu menjadi "pincang" karena tidak memenuhi jumlah minimum anggota Direksi. Dalam keadaan seperti inilah banyak BPR yang harus bergerak cepat untuk mencari Direksi baru karena OJK menetapkan batas waktu bagi BPR untuk melakukan menetapkan Direksi baru. Namun, jangka waktu 120 (seratus dua puluh) hari yang ditetapkan berdasarkan Pasal 33 POJK menimbulkan penafsiran ganda, yakni:

a. Dalam jangka waktu 120 (seratus dua puluh) hari BPR harus sudah mengajukan nama calon Direksinya berdasarkan

20 Try Widiyono, op.cit., hlm. 137.

21 Pasal 32 POJK. 
RUPS di bawah tangan yang perseroan yang bersangkutan; ataukah

b. Dalam jangka waktu 120 (seratus dua puluh) hari BPR telah mendapatkan direksi pengganti yang disetujui dan ditetapkan oleh OJK.

Pasal 33 POJK ini tidak dilengkapi dengan penjelasan.

Untuk menafsirkan ketentuan Pasal 33 POJK, penulis kembali pada UUPT. Pasal 107 UUPT menyebutkan bahwa setiap anggaran dasar perseroan, diatur mengenai (i) tata cara pengunduran diri anggota Direksi, (ii) tata cara pengisian jabatan anggota Direksi yang tidak terisi, (c) ketentuan mengenai penggantian jabatan Direksi sementara. ${ }^{22}$ Hasil penelusuran sumber bahan hukum, penulis mengumpulkan 2 (dua) anggaran dasar milik BPR yang tidak ingin disebutkan nama dan tempat kedudukannya. Dari 2 (dua) contoh anggaran dasar BPR, di dalamnya menyebutkan bahwa:

"Jika oleh suatu sebab apapun jabatan seorang atau lebih atau semua anggota Direksi tidak terisi, maka dalam jangka waktu 30 (tiga pulu) hari sejak terjadi keadaan dimaksud, harus segera diselenggarakan RUPS untuk mengisi jabatan anggota Direksi itu dengan memperhatikan ketentuan perundangundangan dan anggaran dasar".

Berarti, jika ditafsirkan secara a contrario, RUPS yang diadakan untuk menetapkan pengganti Direksi tidak boleh diadakan lebih dari 30 (tiga puluh) hari. Dengan demikian, dalam hal jabatan Direksi lowong maka dalam waktu 30 (tiga) puluh hari, RUPS menetapkan nama atau nama-nama calon pengganti Direksi untuk dapat segera diajukan kepada OJK, sehingga penetapan Direksi pengganti bisa diperoleh BPR sebelum jangka waktu 120 (seratus dua puluh) hari sebagaimana yang ditentukan Pasal 33 POJK.

Membaca kembali anggaran dasar BPR yang berbentuk perseroan terbatas, di ayat selanjutnya dalam pasal yang sama:

"Jika oleh sebab apapun semua jabatan Direksi tidak terisi, untuk sementara perseroan diurus oleh anggota Dewan Komisaris yang ditunjuk oleh Rapat Dewan Komisaris"

Jadi, selama menunggu RUPS menetapkan pengganti Direksi, maka Dewan Komisaris menunjuk anggotanya untuk mengurus perseroan sementara waktu hanya sampai 30 (tiga puluh) hari atau sampai RUPS menetapkan pengganti Direksi.

Kembali kepada POJK, dalam hal salah satu atau semua anggota Direksi maka BPR harus mengajukan nama atau nama-nama calon pengganti anggota Direksi kepada OJK dalam jangka waktu paling lama 120 (seratus dua) hari. Dari calon yang diajukan tersebut, OJK berhak menentukan lolos atau tidaknya calon yang diajukan dalam jangka waktu selambatlambatnya 30 (tiga puluh) hari sejak berkasberkas dan persyaratan pengajuan diterima lengkap oleh OJK. Dalam hal OJK menerima pengajuan calon anggota Direksi BPR, maka dalam jangka waktu paling lama 90 (sembilan puluh) hari sejak tanggal persetujuan OJK, 
BPR harus segera menyelengarakan RUPS untuk mengangkat Direksinya. Kemudian berdasarkan Pasal 94 UUPT, Direksi wajib memberitahukan perubahan anggota Direksi kepada Menteri untuk dicatat dalam daftar Perseroan dalam jangka waktu paling lambat 30 (tiga puluh) hari sejak tanggal keputusan RUPS.

Proses pengajuan calon Direksi oleh BPR ke OJK tidak selalu diterima. Jika si calon Direksi yang diajukan oleh BPR tersebut gagal, bukan karena peraturan OJK yang salah, tapi bisa juga disebabkan pada calon Direksi yang bersangkutan karena tidak memenuhi kualifikasi yang ditetapkan oleh OJK. ${ }^{23}$ Ada kalanya calon yang diajukan oleh BPR ditolak oleh OJK. Dalam hal OJK menolak calon yang diajukan itu, maka pemegang saham BPR harus segera mengajukan kembali nama lainnya sebagai calon anggota Direksinya. Kejadian seperti ini tidak hanya dialami oleh 1 (satu) BPR saja, tapi beberapa bank maupun BPR beberapa daerah pun pernah mengalami hal serupa sehingga bank atau BPR itu hanya memiliki 1 (satu) orang direksi saja walaupun mereka telah beberapa kali mengajukan namanama calon Direksinya. ${ }^{24}$ Dalam keadaan seperti ini, meski BPR telah mengajukan nama calon anggota Direksinya beberapa kali dan dibalas penolakan oleh OJK hingga lewat batas waktu 120 (seratus dua puluh) hari. Sementara di lain sisi, Pasal 88 mengatur adanya sanksi apabila BPR tidak memenuhi jangka waktu pemenuhan jumlah minimum anggota Direksi, yaitu adanya sanksi berupa teguran tertulis, penurunan tingkat kesehatan BPR satu predikat, larangan pembukaan jaringan kantor dan kegiatan Pedagang Valuta Asing (PVA) dan/atau penghentian sementara sebagian kegiatan operasional BPR.

POJK tidak mengatur keadaan dimana jangka waktu pemenuhan jumlah minimum anggota direksi BPR tidak terpenuhi walaupun BPR telah mengajukan permohonan penetapan calon Direksinya. UUPT juga tidak mengatur keadaan yang demikian. UUPT hanya memberikan kewenangan kepada anggaran dasar untuk menetapkan pejabat Direksi sementara. Ini berarti terdapat kekosongan hukum, yaitu suatu keadaan terdapat hal-hal atau keadaan yang tidak atau belum diatur. Kembali kepada teori yang dikemukakan Lon L. Fuller, agar hukum dapat bekerja dengan baik harus memenuhi 8 (delapan) prinsip moral yaitu ${ }^{25}$ :

a. Generality

Generalitas dari undang-undang yang artinya keberadaan dari hukum adalah suatu keharusan yang tidak dapat ditolak.

b. Promulgation

Peraturan tersebut harus diumumkan kepada publik

23 Koran Jakarta, “OJK Pelajari Kembali Hasil Tes Direksi Bank Dari BI”, http://koran-jakarta.com/?3926-ojk+p elajari+kembali+hasil+tes+direksi+bank+dari+bi, diakses 3 Desember 2015.

24 Sinar Pagi, “Anggota DPRD Panggil Direksi Bank Sumsel Babel”, http:/www.sinarpaginews.com/fullpost/ nasional/1420473336/anggota-dprd-panggil-direksi-bank.html, diakses 1 Desember 2015.

25 Gunawan Widjaja, “Lon Fuller, Pembuatan Undang-undang dan Penafsiran Hukum”, Jurnal Fakultas Hukum Universitas Pelita Harapan Jakarta Vol. 6 No. 1, (Juli 2006): 22. 
c. Prospectivity

Hukum tidak boleh berlaku surut.

d. Clarity

Suatu peraturan haruslah dibuat dalam rumusan yang dapat dimengerti oleh umum

e. Consistency or avoiding contradiction Suatu peraturan tidak boleh bertentangan antara satu dengan lainnya.

f. Posibility of obedience

Pembuat undang-undang tidak membuat peraturan yang tidak mungkin tidak dapat dilaksanakan.

g. Consistency through time or avoidance of frequent change

Peraturan tidak boleh sering diubah-ubah oleh pembuat undang-undang.

h. Congruence between official action and declared rules.

Harus ada kesusuaian antara peraturan dan pelaksanaan sehari-hari.

Menurut Lon L. Fuller yang dikutip oleh M. Sulaeman Jajuli, antara peraturan dengan pelaksanaannya haruslah ada kepastian dengan demikian hukum dapat memasuki ranah aksi, perilaku dan faktor-faktor yang mempengaruhi bagaimana hukum positif itu dijalankan. ${ }^{26}$ Kepastian hukum bukan saja penting karena terkait dengan pengaturan dalam bentuk abstrak tapi juga penting terkait dengan penerapannya pada kasus konkret. Praktisi BPR menunggu hasil penetapan Direksi oleh OJK sementara batas 120 (seratus dua puluh) hari untuk memenuhi jumlah minimum anggota Direksi telah terlampaui. Di sinilah tampak ketidaksesuaian antara peraturan antara peraturan dengan pelaksanaan sehari-hari.
Selama ini, apabila OJK menilai calon Direksi yang diajukan BPR tidak memenuhi kualifikasi yang ditetapkan oleh OJK, BPR secara terus menerus mengajukan nama calon Direksinya dan akan tetap mengajukan sampai OJK menetapkan calon Direksi yang memenuhi kualifikasi OJK. Bagi BPR yang hanya memiliki 1 (satu) orang Direksi, tentunya hal ini akan menyebabkan terhambatnya operasional bisnis mereka. Dalam keadaan seperti ini, hendaknya OJK dapat membuat suatu kebijakan bagi BPR yang mengalami keadaan seperti ini agar BPR yang bersangkutan dapat mengajukan Direksi sementara sampai BPR itu mendapatkan calon Direksi yang lolos penilaian OJK sehingga operasional BPR tidak sampai terhambat.

Mencermati kembali UUPT, UU Perbankan dan POJK, keseluruhan peraturan tersebut memungkinkan BPR untuk memiliki lebih dari 2 (dua) orang anggota Direksi. Selama ini, kebanyakan BPR memilih untuk memiliki 2 (dua) orang anggota Direksi saja, sesuai dengan jumlah minimum yang ditetapkan oleh Undang-undang dan peraturan lainnya dengan alasan menghemat biaya operasional BPR. Namun, jika salah satu anggota Direksinya tidak terisi, tentunya BPR akan mengalami keadaan yang diuraikan di atas. Oleh karenanya, akan lebih bijaksana jika BPR mengangkat lebih dari 2 (dua) orang anggota Direksi. Jika BPR merasa terbebani dengan susunan Direksi yang tidak 
ramping, BPR hendaknya dapat mensiasati untuk mengkader karyawannya untuk dididik menjadi professional handal di bidang perbankan agar kelak dapat menggantikan anggota Direksi yang suatu saat meninggalkan BPR tersebut.

\section{B. Perbuatan Hukum RUPS Selama Direksi Perseroan tidak Memenuhi Jumlah Minimum}

Direksi dalam suatu perseroan merupakan suatu organ yang bertanggung jawab dalam pengurusan perseroan sehari-hari. UUPT memberikan kewenangan kepada Direksi untuk mewakili PT baik di dalam maupun diluar pengadilan. ${ }^{27}$ Kewenangan mewakili perseroan ini tidak dimiliki oleh organ perseroan lainnya dan untuk menjalankan kewenangan tersebut, Direksi tidak memerlukan surat kuasa atau dokumen pendelegasian dari organ perseroan lainnya. Direksi yang mewakili perseroan bertindak berdasarkan kuasa menurut hukum (legal mandatory) yang artinya PT sendiri telah menetapkan seseorang yang menurut hukum bertindak mewakili orang atau badan hukum tanpa memerlukan surat kuasa. ${ }^{28}$ Selain itu, Pasal 98 ayat (3) UUPT memberikan kewenangan "tidak terbatas" dan "tidak bersyarat", kecuali ditentukan lain dalam UUPT, anggaran dasar dan RUPS.

Salah satu implikasi pelaksanaan POJK dalam hal penetapan anggota Direksi yang diuraikan pada sub bab sebelumnya adalah BPR dapat mengalami suatu keadaan dimana jumlah organ perseroan yang bernama Direksi tidak memenuhi jumlah yang ditetapkan oleh UUPT dan POJK. Penulis mencoba mencermati ketentuan yang terdapat di dalam UUPT. Penulis mencermati esensi Pasal 118 ayat (1) dimana di dalamnya memberikan kewenangan kepada anggaran dasar atau RUPS agar Dewan Komisaris dapat melakukan tindakan pengurusan perseroan dalam keadaan tertentu untuk keadaan tertentu. Penjelasan Pasal 118 ayat (1) UUPT memberikan definisi yang sangat jelas menganai apa yang dimaksud dengan"keadaan tertentu" tersebut, yaitu Direksi (i) Direksi tidak ada, (ii) seluruh anggota Direksi mempunyai benturan kepentingan dengan perseroan (Pasal 99 ayat (2) UUPT), (iii) seluruh anggota Direksi berhalangan dan (iv) seluruh anggota Direksi diberhentikan untuk sementara (Pasal 107 huruf c).

Apabila Direksi tidak ada, maka sesuai ketentuan Pasal 118 ayat (1) UUPT, Dewan Komisaris dapat mengurus perseroan untuk sementara waktu. Dalam hal Dewan Komisaris menggantikan organ perseroan yang bernama Direksi, maka pada detik setelah terjadinya keadaan dimana Direksi tidak ada, seluruh hak, wewenang dan kewajiban yang sebelumnya melekat kepada Direksi berpindah kepada Dewan Komisaris, termasuk dalam hubungan atau perbuatan hukum 
dengan pihak ketiga. ${ }^{29}$ Dewan Komisaris atau anggota Dewan Komisaris yang ditunjuk oleh Dewan Komisaris untuk menjadi pejabat Direksi sementara dapat melakukan kegiatan perseroan, dengan catatan untuk hal-hal atau perbuatan hukum tertentu perseroan harus tetap memperhatikan anggaran dasar, seperti:

"Perbuatan hukum untuk mengalihkan, melepaskan hak atau menjadikan jaminan utang yang merupakan lebih dari 50\% (lima puluh persen) jumlah kekayaan bersih perseroan dalam satu tahun buku, baik dalam satu transaksi atau beberapa transaksi yang berdiri sendiri ataupun yang berkaitan satu sama lain harus mendapatkan persetujuan RUPS yang dihadiri atau diwakili para pemegang saham yang memiliki paling sedikit $3 / 4$ (tiga per empat) bagian dari jumlah seluruh saham dengan hak suara yang sah dan disetujui oleh paling sedikit $3 / 4$ (tiga per empat) bagian dari jumlah seluruh suara yang dikeluarkan secara sah dalam rapat" 30

Cornelius Simanjuntak dan Natalie Mulia berpendapat bahwa untuk perpindahan segala wewenang dan tanggungjawab Direksi kepada Dewan Komisaris tidak memerlukan formalitas tertentu karena hal tersebut telah diatur sedemikian rupa oleh anggaran dasar ataupun RUPS. ${ }^{31}$ Namun menurut pendapat penulis, adanya suatu formalitas diperlukan untuk menunjukan posisi Dewan Komisaris sebagai pejabat Direksi sementara kepada pihak ketiga. Hal tersebut merupakan suatu justifikasi bahwa Dewan Komisaris telah menunjuk salah satu anggotanya untuk melaksanakan fungsi Direksi sementara. Dengan diambilalihnya fungsi organ Direksi oleh Dewan Komisaris untuk sementara waktu, maka pada saat yang sama Dewan Komisaris memiliki peran ganda, yakni selaku Dewan Komisaris yang bertugas mengawasi Direksi sekaligus sebagai pejabat sementara perseroan yang "diawasi” oleh dirinya sendiri.

Mengkaji kembali teori organ yang dikemukakan pada bab sebelumnya, masingmasing organ perseroan yaitu RUPS, Direksi dan Dewan Komisaris masing-masing telah tugas dan wewenang, seperti hal-nya manusia yang memiliki organ-organ, seperti tangan, kaki, mata, telinga dan seterusnya. Adanya percampuran organ (antara Direksi dan Dewan Komisaris) akan berakibat ketidakefektifan dalam melakukan fungsi pengawasan di internal perseroan. Hal tersebut akan dapat membuka celah penyimpangan yang dapat merugikan perseroan.

Selain itu, tidak terpenuhinya jumlah minimum anggota Direksi sama halnya dengan tidak terpenuhinya syarat formalitas suatu badan hukum. Merujuk ke Pasal 14 UUPT, ketika suatu perseroan belum memperoleh status badan hukum, maka Direksi, seluruh anggota Dewan Komisaris dan pendiri perseroan bertanggungjawab secara renteng atas perbuatan hukum yang dilakukan oleh perseroan tersebut. Dalam keadaan dimana

29 Cornelius Simanjuntak dan Natalie Mulia, op.cit., hlm. 89.

30 Pasal 14 Anggaran Dasar Perseroan.

31 Cornelius Simanjuntak dan Natalie Mulia, loc.cit. 
jumlah minimum tidak terpenuhi, BPR tidak dapat melakukan perbuatan hukum, meskipun dalam anggaran dasar memungkinkan pelimpahan wewenang sementara kepada Dewan Komisaris. Perbuatan hukum yang tetap dilakukan selama tidak terpenuhinya jumlah minimum anggota Direksi menyebabkan adanya tanggung jawab secara renteng antara Direksi, Dewan Komisaris dan pemegang saham.

\section{Simpulan}

Berdasarkan uraian pada pembahasan terhadap permasalah yang diteliti, maka penulis menarik kesimpulan:

1. Ketentuan dalam POJK sehubungan dengan penetapan anggota Direksi BPR tidak memberikan kepastian hukum bagi BPR sebagai obyek dari peraturan tersebut. Pengajuan nama calon anggota Direksi BPR yang berulang-ulang kepada OJK dengan alasan calon yang diajukkan tidak memenuhi Uji Kemampuan dan Kepatutan, menyebabkan BPR tidak kunjung dapat menetapkan susunan anggota Direksinya sementara hal dimaksud bukanlah mutlak kesalahan BPR. POJK tidak mengatur apa yang seharusnya dilakukan oleh BPR jika dalam jangka waktu 120 (seratus dua puluh) hari nama-nama calon yang diajukan oleh BPR tidak lolos seleksi OJK. Akibatnya, BPR tidak memenuhi jumlah minimum anggota Direksi BPR sebagaimana yang ditentukan pada UUPT, UU Perbankan dan POJK bahkan dalam keadaan tertentu sama sekali tidak memiliki anggota Direksi. Selain tidak dapat memenuhi jumlah minimum anggota Direksi, BPR juga dikenai sanksi berdasarkan Pasal 88 POJK.

2. RUPS harus segera menunjuk nama calon anggota Direksi untuk segera dimintakan penetapan sebagai Direksi kepada OJK. Selama lowongnya posisi anggota Direksi, berdasarkan anggaran dasar perseroan, maka Dewan Komisaris dapat menunjuk salah satu anggotanya untuk menggantikan posisi Direksi yang lowong. Namun adanya overlapping atau tumpang tindih jabatan ini dapat menciptakan celah adanya penyimpangan dalam menjalankan usaha dan juga dapat menimbulkan penyalahgunaan wewenang. Perbuatan hukum yang tetap dilakukan selama badan hukum tidak memenuhi persyaratan formal, dapat menyebabkan perbuatan hukum tersebut menjadi tanggung jawab secara renteng antara Direksi, Dewan Komisaris dan pemegang saham. 


\section{DAFTAR PUSTAKA}

\section{Buku}

Harris, Freddy dan Teddy Anggoro. Hukum Perseroan Terbatas: Kewajiban Pemberitahuan Direksi sebagai Pengurus dan Wakil Perseroan. Jakarta: Ghalia Indonesia, 2010.

Hermansyah, Hukum Perbankan Nasional Indonesia. Jakarta: Kencana Prenada Media Group, 2012.

Jajuli, M. Sulaeman. Kepastian Hukum Gadai Tanah Dalam Islam. Yogyakarta: Deepublish, 2012.

Orinton Purba, Petunjuk Praktis Bagi RUPS, Komisaris dan Direksi Perseroan Terbatas Agar Terhindar Dari Jerat Hukum. Jakarta: Raih Asa Sukses, 2011Simanjuntak, Cornelius dan Natalie Mulia. Organ Perseroan Terbatas. Jakarta: Sinar Grafika, 2009.

Sutedi, Adrian. Aspek Hukum Otoritas Jasa Keuangan. Jakarta: Raih Asa Sukses, 2014.

Widiyono, Try. Direksi Perseroan Terbatas. Bogor: Ghalia Indonesia, 2008.

Yani, Ahmad dan Gunawan Widjaja. Seri Hukum Bisnis Perseroan Terbatas. Jakarta: Rajawali Pers, 1999.

\section{Peraturan Perundang-undangan}

Undang-undang Nomor 40 Tahun 2007 tentang Perseroan Terbatas.
Undang-undang Nomor 21 Tahun 2011 tentang Otoritas Jasa Keuangan.

Peraturan Otoritas Jasa Keuangan Nomor 20/POJK.03/2014 tentang Bank Perkreditan Rakyat.

\section{Surat Kabar}

Koran Jakarta. “OJK Pelajari Kembali Hasil Tes Direksi Bank Dari BI". http:// koran-jakarta.com/?3926-ojk+pelajari +kembali+hasil+tes+direksi+bank+dar i+bi. Diakses 3 Desember 2015.

Suara Merdeka. "Peraturan OJK Memperkuat BPR". http://berita.suaramerdeka. $\mathrm{com} / \mathrm{smcetak} /$ peraturan-baru-ojkmemperkuat-bpr. Diakses 6 Juni 2016.

Sinar Pagi. "Anggota DPRD Panggil Direksi Bank Sumsel Babel”. http:// Www.sinarpaginews.com/fullpost/ nasional/1420473336/anggota-dprdpanggil-direksi-bank.html. Diakses 1 Desember 2015.

\section{Jurnal}

Widjaja, Gunawan. "Lon Fuller, Pembuatan Undang-undang dan Penafsiran Hukum", Jurnal Fakultas Hukum Universitas Pelita Harapan Jakarta Vol. 6 No. 1, (Juli 2006): 22. 